\title{
Quantifying the impacts of subsidy policies on home-to-school pupil travel by bus in England
}

\author{
Jessica A. Van Ristell • Mohammed A. Quddus • Marcus P. Enoch • \\ Chao Wang • Peter Hardy
}

Published online: 29 May 2014

(C) The Author(s) 2014. This article is published with open access at Springerlink.com

\begin{abstract}
In the current economic climate, the British Government is revising a whole range of policy sectors to highlight areas where savings and cuts can be made. The policy of subsidising home-to-school transport for pupils who live beyond a set distance from the school which they attend has been in place since 1944 and this policy costs local authorities in England over $£ 1$ billion a year. The aim of this paper is to examine the outcomes of policy choices facing Government relating to subsidising the transport of pupils travelling between home and school. Specifically, the paper employs a multilevel modelling technique to develop a series of relationships between bus usage by school and the level of spending by local education authorities on home-to-school bus travel provision while controlling for other factors such as school quality, land-use patterns and various proxies for household incomes. The results suggest that there is a differential effect of funding on the total school-level bus mileage for primary (aged $<11$ ), secondary (aged 11-16) and post 16 schools. It is found that if local authority school budgets for bus travel provision were removed, then school-level bus mileage in England would decrease by 16, 27 and $10 \%$ for primary, secondary and post 16 schools respectively. It is hoped that the results of the study will help inform practitioners and policy makers to select the policy responses that are most appropriate.
\end{abstract}

\footnotetext{
J. A. Van Ristell

Operational Analysis Safety Team, NATS, 4000 Parkway, Whiteley, Fareham PO15 7FL, Hampshire, UK
}

M. A. Quddus · M. P. Enoch ( $\square)$

Transport Studies Group, School of Civil and Building Engineering, Loughborough University, Loughborough LE11 3TU, Leicestershire, UK

e-mail: m.p.enoch@lboro.ac.uk

C. Wang

Medical Sciences Division, University of Oxford, Oxford OX3 9DU, UK

P. Hardy

JMP Consultants Ltd, 85-89 Colmore Row, Birmingham B3 2BB, UK 
Keywords Education policy - School pupil bus transport - Fare subsidy - Multilevel modelling $\cdot$ Mode choice $\cdot$ Transit $\cdot$ Impacts

\section{Introduction}

After nearly three decades of sustained economic growth in the western world, difficulties in the US housing market emerged during 2007, thus precipitating a major banking crisis which subsequently led to a global economic recession (Stiglitz 2010). Accordingly, on the 20th October 2010, the British Government announced that it was to cut $£ 81$ bn of public spending by 2015 (BBC 2010). Such a decision would clearly impact on local authority budgets, and hence there was a focus on potential areas where savings can be made.

One such budget area is the subsidising of home-to-school transport by local authorities (LA) which in 2009-2010 amounted to more than $£ 1$ billion (DfE 2010a). Although the majority of this amount is spent on 'special educational needs' (SEN) travel (travel for students with learning and/or physical disabilities) and hence is difficult to reduce, funds of over $£ 400 \mathrm{~m}$ were still spent by LA in England on subsidising home-to-school transport provision to roughly half-a-million pupils, a sum which amounts to around 2-3\% of their annual expenditure. Moreover, this money is granted based on legislation that has remained largely unchanged since the Second World War (Thornthwaite 2009), in spite of significant changes in circumstances since then. Thus, the 1944 Act assumes for example that two parent families are the norm (and that one parent works whilst the other is free to take their younger children to and from school); and that parents will not worry too much about their children being victims of traffic accidents or abduction by strangers (and so be prepared to allow their older children to walk up to three miles unaccompanied) (Audit Commission 2001).

On the other hand however, in a review of the available evidence, Mackie (2001) reported that overall there is a 'respectable case' for subsidising bus services generally against the textbook criteria of public goods, increasing returns to scale and externalities, providing that it is applied across the network and not just to non-commercial services, and that 'leakage' (where subsidy contributes to higher operating costs) is minimised through careful design of how the system was designed. Moreover, in considering these arguments for subsidising pupil travel to school by bus, one might argue that returns to scale should be at least as strong as for general subsidies particularly given that for every bus trip lost to the car, then two car trips are typically generated (because children cannot legally drive themselves and need to be escorted). Similarly, one could imagine additional externality benefits of subsidising pupil bus travel not only including (peak time) congestion savings and less serious road traffic accidents, but also some longer term benefits caused by increasing levels of independence from adults, and from improved health outcomes (less asthma, and less serious respiratory and obesity problems) (Thornthwaite 2001).

In attempting to resolve these conflicting pressures therefore, the UK Government initiated a review to explore efficiency and practice in the procurement, planning and provision of school transport across England (DfE 2011), although the end result (see DfE 2013), is actually a guidance document for LA, parents and schools that seeks to clarify existing rules and regulations. As a result, the aim of this paper is to quantitatively examine the policies relating to the funding criteria of home-to-school public school transport provision.

While clearly this case study focuses on the situation in England, it also has international relevance. Firstly, this is because the increasing use of the car around the world for 
home-to-school trips is leading to the problems already outlined, and so having a better understanding the factors that influence car use levels for educational journeys is likely to be of value. Second, there are implications for concessionary fare schemes more generally. Third, while decisions made by policy makers everywhere can have major implications for society, it is often the case that these are made in the absence of appropriate information, with the result that such decisions may be sub-optimal.

Accordingly, there is a need for better evidence to enable policy makers to make better informed decisions, which translates into a process whereby realistic results against a number of criteria for a range of policy alternatives can be predicted in a short time frame, using accessible (ideally pre-existing) data and models, in an easy to understand format. Overall then, this paper is significant in that it helps to provide an indication of the degree to which reduced bus subsidies could generate extra car trips and in presenting a practicable methodology for policy makers across transport and broader topic areas to evaluate policy choices in a more robust manner than currently. The novelty stems from its application to the school travel sector, and in its use of hierarchical multilevel modelling in which it is possible to include both school policy variables at the local authority level and school quality variables at the school level. In addition, this modelling strategy will facilitate to investigate the effect of cross-level (between school and local authority) interaction terms. This kind of modelling strategy has not been applied to this topic in the past. Finally, at this point it should be noted that this paper complements two previously published papers on the subject of school transport policy, firstly quantifying the transportrelated impacts of school choice policy in the UK (Van-Ristell et al. 2013a) and secondly looking at expert perspectives on the role of the bus in school travel (Van-Ristell et al. 2013b).

The paper is structured as follows; "Previous research" section explores the previous research undertaken in this area and "School travel in England" section examines the context of school travel in England. "Method" section outlines the methods used in this analysis and "Data" section explains the data used in this study. The results and a discussion will be presented in "Model estimation results" and "Discussion" sections and finally conclusions will be provided in "Conclusions" section.

\section{Previous research}

In looking at research into school transport, when compared to travel by other modes (particularly the car, bicycle and walking) there are relatively few studies relating to school travel by bus. Moreover, those which do exist focus on a relatively small number of topic areas, namely:

- School bus route optimisation studies (including Park and Kim 2010; Chen et al. 1988; and Fügenschuh 2009);

- School bus safety issues (as explored by Swartz and Reilly 1995; and Yang et al. 2009) and

- Emissions in and around school buses (researched by Zhang and Zhu 2010; Hochstetler et al. 2011; and Gao and Klein 2011).

In addition, there is a limited body of work on research topics such as the behaviour of children on buses to school (including Whitehurst and Miller 1973; Luiselli 1978) and the use of alternative fuels for school buses (Cohen 2005). Interestingly though, there is actually relatively little material published as to the effect of policy decisions on school bus 
travel, in spite of the relatively high political profile of the 'school run' (Kingham and Ussher 2005). Specifically, there are two main areas of policy-focused research within school bus travel. First, several studies look into dedicated school buses (for example, the Yellow Bus Commission 2008). Second, home-to-school public transport provision is explored by Thornthwaite (2009), who reviews international evidence on the current policies offered and by Hine (2009) who explores the home-to-school public transport provision of Northern Ireland. Both studies state that finance and funding are key in providing transport services to school children. However, as yet no in-depth quantitative studies seem to have been conducted at the national level examining the effects of changing these policies, and it is this gap that this paper seeks to address.

To do this, it is helpful to briefly identify the key factors that might influence how pupils travel to school from a theoretical standpoint. Thus, in an ideal world, theory suggests that an analysis of pupil bus miles (effectively a blend of 'destination choice' and 'mode choice' problems) would consider a whole range of factors (see de Ortuzar and Willumsen 2001). Looking first at destination choice, key factors here relate to the attractiveness of the destination vis a vis other possible destinations. And for mode choice, they suggest that the most influential factors include:

- trip maker characteristics (car availability, possession of a driving licence, household structure, decisions made elsewhere — such as opportunity for trip chaining — and residential density);

- trip characteristics (trip purpose, length and time of day); and

- transport mode factors (relative time and monetary cost of available travel choices, availability and cost of car parking, comfort and convenience, reliability and regularity, and protection/security concerns).

Looking specifically at influences on mode choice school travel meanwhile, Van-Ristell et al. (2013a) reviewed the factors affecting travel behaviour of the journey to school and found that these comprised of area factors (journey distance, how urban an area is, degree of income deprivation, residential location and road density); household and parental factors (household structure, parental employment status, household income); personal factors (age, gender, ethnicity); and policy factors (both directly and indirectly related to school travel). Similarly, Thornthwaite (2001) outlined car ownership, family lifestyles (e.g. both parents working), perceived and actual road and personal safety, distance, availability of alternative modes, lack of locker space (e.g. if books, sport equipment or musical instruments need to be carried), and peer pressure/expectations/convenience as being key.

In practical terms, the story throughout the developed world has been that average distances to school have generally increased over recent decades, and that partly as a consequence the proportion of motorised home-to-school trips (particularly car use) has increased at the expense of non-motorised modes such as walk and cycle.

\section{School travel in England}

In terms of how the education system is organised, there are over 26,000 schools teaching more than 9 million school aged children residing in England, of which 7 million (DfE $2010 \mathrm{~b}$ ) are of 'compulsory' school age (aged between 5 and 16 years) and are therefore required to attend school by law (ONS 2006). Of these schools, over 21,000 are 'Government maintained' or 'state' schools which are funded through LA. Specifically, LA (or 
councils) are the Government bodies concerned with the delivery of local services, including education and transport (see Abbott et al. (2012) and Headicar (2009) for an indepth commentary on institutional arrangements for the UK education and transport sectors respectively). In total, there are 152 LA in England. Overall, in 2010, $6.4 \%$ of UK Government expenditure was spent on education (Chowdry and Sibieta 2011), while roughly $13 \%$ of local authority expenditure was allocated for education purposes (Chantrill 2011).

Of the remainder, so-called 'grant maintained' schools, academies, faith denominational schools are instead directly funded from central Government. There are also private 'independent' schools which are usually funded through parents paying fees. All these different types of schools normally follow the same curriculum as 'maintained' schools but are not funded directly from the local Government they are not included in the School Census and therefore are not covered by the statistics used in this study. Schools in England are (mostly) divided into three main age groups of primary school (ages 5-11), secondary school (ages 11-16) and post 16 (usually ages 16-19). Children are generally educated on the basis of a national curriculum basis of a national curriculum (DfE 2013a):

- Age 5-7 Key Stage 1

- Age 7-11 Key Stage 2

- Age 11-14 Key Stage 3

- Age 14-16 Key Stage 4 (GCSE or GNVQ ordinary school level examinations)

- Age 16 + GCE 'A' Level or NVQ (advanced school level examinations)

In looking at home-to-school travel patterns, in 1989/91 such trips accounted for $10 \%$ of daily personal trips (up to $14 \%$ at the peak time of 08.50 in the morning peak) and on average were 2.0 miles long, whilst $56 \%$ were made by walking and $21 \%$ by car. Moreover, at that time nearly a third of pupils (31\%) travelled independently (DfT 2003). Worryingly however, these figures have worsened significantly over time. Thus, although home-to-school trips made up a similar proportion of all trips in 2011 (i.e. $11 \%$ ), the proportion of car traffic from home-to-school trips made up almost a quarter of peak vehicle journeys (10 min earlier at 08.40) and the average trip distance had risen by $20 \%$ to 2.5 miles. Meanwhile the modal share of walking dropped by $15 \%$ to only $39 \%$; that of car use effectively doubled to $43 \%$ over the same 20 year period; and the proportion of independent travellers had fallen to only $22 \%$. One minor positive perhaps, was that local (public) bus use actually increased slightly from 11 to $13 \%$ between 1998/1999 and 2011 (DfT 2003 and DfT 2012). Breaking down these figures a little, it is clear (and unsurprising) that primary school pupils (aged 5-10) travel half as far to and from school as do secondary pupils (11-16); walk and use the car more but use the bus and bicycle less often; and are far less independent (only $6 \%$ are unescorted compared to $39 \%$ ). Also, rural pupils travel further than pupils in more urbanised areas, whilst pupils in London use public transport modes the most, and females are driven to school more often than males.

In explaining these figures, as alluded to earlier, commentators suggest that such trends were due to broader socio-economic factors (e.g. increased car ownership, increased fear of 'stranger danger', more families where both parents work), as well as such policy decisions as allowing parents to decide which school to send their children to (Van-Ristell et al. 2013a, b).

One responsibility of LAs, (costing on average around 2-3\% of their total annual budgets), is to ensure that eligible children are provided with subsidised travel between their home and school under the requirements of the Education Act 1944 and its subsequent (minor) modifications - see Table 1 for details of these. 
Table 1 Legislative developments in UK home-to-school transport provision

\begin{tabular}{|c|c|}
\hline Legislation adopted & Key features \\
\hline 1944 Education Act & $\begin{array}{l}\text { Placed a duty on Local Education Authorities to provide home-to-school } \\
\text { transport beyond certain walking distances ( } 2 \text { or } 3 \text { miles according to age) } \\
\text { to facilitate attendance }\end{array}$ \\
\hline 1980 Education Act & $\begin{array}{l}\text { Introduction of the right of parents to choose a school for their child. } \\
\text { However, eligibility for free school transport did not change from the } 1944 \\
\text { Education Act }\end{array}$ \\
\hline $\begin{array}{l}1988 \text { Education Reform } \\
\text { Act }\end{array}$ & $\begin{array}{l}\text { Introduction of grant maintained schools and delegated funding to individual } \\
\text { schools. Strengthened parental preference. School transport still funded by } \\
\text { LA as before }\end{array}$ \\
\hline $\begin{array}{l}1992 \text { Further \& Higher } \\
\text { Education Act }\end{array}$ & $\begin{array}{l}\text { Duty to treat young people at colleges the same as those at school sixth forms } \\
\text { with regard to the provision of transport. Many authorities introduced } \\
\text { charges for all post-16 transport }\end{array}$ \\
\hline 1996 Education Act & Further defined children who are eligible for free transport \\
\hline 2002 Education Act & Introduced a duty to provide a transport policy statement for post- 16 students \\
\hline 2006 Equality Act & $\begin{array}{l}\text { Consolidated various legislation, removing discrimination including on } \\
\text { transport services }\end{array}$ \\
\hline $\begin{array}{l}2006 \text { Education and } \\
\text { Inspections Act }\end{array}$ & $\begin{array}{l}\text { Introduced a requirement for LA to produce a Sustainable Modes of Travel to } \\
\text { School Strategy. Widened the eligibility criteria to provide free transport } \\
\text { for children from low income families }\end{array}$ \\
\hline
\end{tabular}

Sources Thornthwaite (2009), Gillard (2011), DfE (2013a)

In brief, the message arising from the legislation is that LA have a responsibility of aiding those living beyond certain distances of their nearest school (2 miles for primary school age and 3 miles for secondary school age) in the form of free transport (DfE 2013). Aid in the travel to school provided to eligible pupils is usually in the form of a subsidised free bus pass, which can either be used on existing bus services that are available to the general public (the availability of which will clearly affect the demand by pupils for the service), or else on 'dedicated' school buses which are specially chartered for use only by children to travel to and from school in term time. Meanwhile pupils considered to have SEN are often provided with transport via a specialist vehicle (e.g. a taxi, minibus or ambulance) instead. Overall, Thornthwaite (2009) reported that as of 2008/9 there were 977,500 pupils in total in receipt of local authority-provided school transport in England (12\% of the school population), of whom around half are understood to qualify through the distance criteria. Non qualifying pupils are required to pay (usually discounted) fares to take the bus to and from school.

\section{Method}

The research design comprised of two parts.

First, a primary data gathering exercise was undertaken to ascertain the policies pertaining to the funding criteria employed by LAs in England for home-to-school transport provision. This involved examining the internet sites of each English local authority in order to determine the stated policies relating to how they decide on which pupils are eligible for subsidised transport for primary, secondary and post 16 pupils. These 'responses' were then coded as being either 'Standard' or 'Generous' (see later for definitions of these terms) and then entered into the database. The primary objective was to 
examine the policies relating to the funding criteria that affect the level of pupil-mile travelled by bus for a single home-to-school trip in England.

Second, a multi-level modelling exercise was applied to determine the pupil-miles travelled by bus per school for the different scenarios tested. This approach was seen as being appropriate based on the assumption that this variable was not only influenced by school level factors (such as, school quality, pupils, ethnicity), but also by factors associated with the local authority (such as, home-to-school bus fare policy, the level of funding and land-use patterns) where the school is located. While a three-level model (pupil, school and local authority) could theoretically have instead been employed for the evaluation of the individual-level effect, this would have required the identification of individuals at the household level to control for income, household structure, etc. Unfortunately, access to individually attributable data was not permitted due to data confidentiality reasons. Hence, a two-level model (school and local authority) was felt to be the most appropriate. See Goldstein (2003) for more details of such techniques.

In a multilevel modelling framework, it would be possible to examine how much variation in school-level pupil-mile travelled by bus is due to school-level factors and how much variation is attributed to local authority-level factors.

The model is shown in the following equation:

$$
Y_{i j}=\beta_{0 j}+\beta_{j} X_{i j}+e_{i j}
$$

where $\mathrm{Y}_{\mathrm{ij}}$ is the dependent variable representing the total pupil bus-mileage for school $i$ in local authority $j, X$ is a school-level factors, $e$ is the school-level residual that is independent across observations and follows a normal distribution with a zero mean and a constant variance: $e \sim N\left(0, \sigma_{e}^{2}\right)$. In addition:

$$
\begin{gathered}
\beta_{0 j}=\gamma_{00}+\gamma_{01} Z+u_{0 j} \quad u_{0} \sim N\left(0, \sigma_{u_{0}}^{2}\right) \\
\beta_{1 j}=\gamma_{10}+\gamma_{11} Z+u_{1 j} \quad u_{1} \sim N\left(0, \sigma_{u_{1}}^{2}\right) \\
\left(\begin{array}{l}
u_{0 j} \\
u_{1 j}
\end{array}\right) \sim \operatorname{MVN}\left(\mathbf{0}, \boldsymbol{\Omega}_{u}\right), \quad \mathbf{0}=\left(\begin{array}{l}
0 \\
0
\end{array}\right), \boldsymbol{\Omega}_{u}=\left(\begin{array}{ll}
\sigma_{u_{0}}^{2} & \sigma_{u_{01}} \\
\sigma_{u_{10}} & \sigma_{u_{1}}^{2}
\end{array}\right)
\end{gathered}
$$

where $\gamma_{00}$ the overall mean pupil bus-mileage across school, $u_{0 j}$ is the effect of local authority $\mathrm{j}$ on the bus-mileage (in which a local-authority effect that follows a normal distribution with mean zero and variance $\sigma_{u_{0}}^{2}, \gamma_{01}$ is the coefficient for the local authoritylevel variable), $\mathrm{Z}$ is an local authority-level independent variable, $u_{1 j}$ is the local authorityspecific random slope for the school-level variable and this is also assumed to follow a normal distribution with mean zero and variance $\sigma_{u_{1}}^{2}, \sigma_{u_{10}}=\sigma_{u_{01}}$ indicates the covariance between $u_{0 j}$ and $u_{1 j}$ Using Eqs. (2) and (3) into Eq. (1) yields the following model:

$$
Y_{i j}=\gamma_{00}+\gamma_{01} Z+\gamma_{10} X+\gamma_{11} X Z+u_{0 j}+u_{1 j} X+e_{i j}
$$

where $\gamma_{11}$ is the coefficient for the cross-level interaction term. If it is thought that Eq. (3) should not include any upper-level (local authority) covariates (Z) then Eq. (4) would not have any cross-level interaction terms.

It is noticeable that Eq. (4) contains both fixed-effects $\left(\gamma_{00}+\gamma_{01} Z+\gamma_{10} X+\gamma_{11} X Z\right)$ and random-effects $\left(u_{0 j}+u_{1 j} X\right)$ and therefore, this can be termed as a multilevel mixed-effect (random-intercept and random-coefficient) linear regression model. From this, Eq. (4) can easily be generalised into the case in which multiple school-level and local authority-level independent variables can be incorporated as follows: 


$$
Y_{i j}=\vartheta \boldsymbol{W}+\boldsymbol{\delta} \boldsymbol{V}+\boldsymbol{\varepsilon}
$$

in which is $\boldsymbol{W}$ a matrix containing the fixed effects independent variables, $\vartheta$ is a vector of fixed effects parameters, $\boldsymbol{V}$ is a matrix containing the random effects, $\vartheta$ is the vector of random effects and $\boldsymbol{\varepsilon}$ is the vector of errors. A model without the inclusion of $\boldsymbol{V}$ can be termed as random-intercept linear regression model and a model without $\boldsymbol{W}$ can be termed as random-coefficient linear regression model. Equation (5) can be estimated using the maximum likelihood (ML) estimation method (see de Ortuzar and Willumsen 2001 for more on this).

The above multilevel model can be used to estimate total bus pupil mileage for all 3 year groups (1) Primary School, (2) Secondary School and (3) Post 16. Within each model, the impacts of changes in budget on bus mileage can be estimated.

\section{Data}

This paper draws on data from the 2009 School Census (DfE 2010b), which is then supplemented by additional information from other sources. In the event, it was not practical to construct a multi-level model with more than two levels (Goldstein 2003), and given the policy focus of the paper it was felt that the school and local authority levels were the most appropriate to model. Accordingly, the factors from the literature review were 'converted' to school and local authority level variables, a process which is illustrated in Table 2.

From this it can be seen which of the 'ideal' variables of interest have been modelled and which have not (together with reasons for rejection/non treatment). So, for example the variables 'school quality' and 'school size' were incorporated to provide an indication of 'destination attractiveness', whilst the variable 'all car activity' was actually used as a proxy to represent a variety of influences including car availability/ownership, road density, and level of road safety. Meanwhile variables such as household structure, household income, convenience and lack of locker space were not modelled due to practical issues such as a lack of suitable data.

In doing this, there are two basic issues with the School Census data which should be noted. First, is that it only provides details of all pupils attending Government funded schools, i.e. around $80 \%$ of the English pupil population. Second, any data collected which might conceivably be used to identify individual children was not made available to the research team due to confidentiality concerns, meaning that some values are based on assumptions. Nevertheless, as this research explores the implications of altering Government funding policy on school transport, this was felt to be the most appropriate dataset to use. The variables used are presented in Table 3 and are arranged by level of analysis (school or local authority), and by data source.

The School Census is an annual survey of all schools run by LA by the Department for Education (which was known as the Department for Children, Schools and Families until May 2010). Overall, the 2009 School Census provides information for over 7.4 million individual pupils across England attending over 21,000 Government maintained schools in 152 LAs. Following from Table 1, this section provides additional explanation of how data variables were created where necessary. First, the dependent variable is the total schoollevel pupil bus mileage that is calculated as in Eq. (6): 


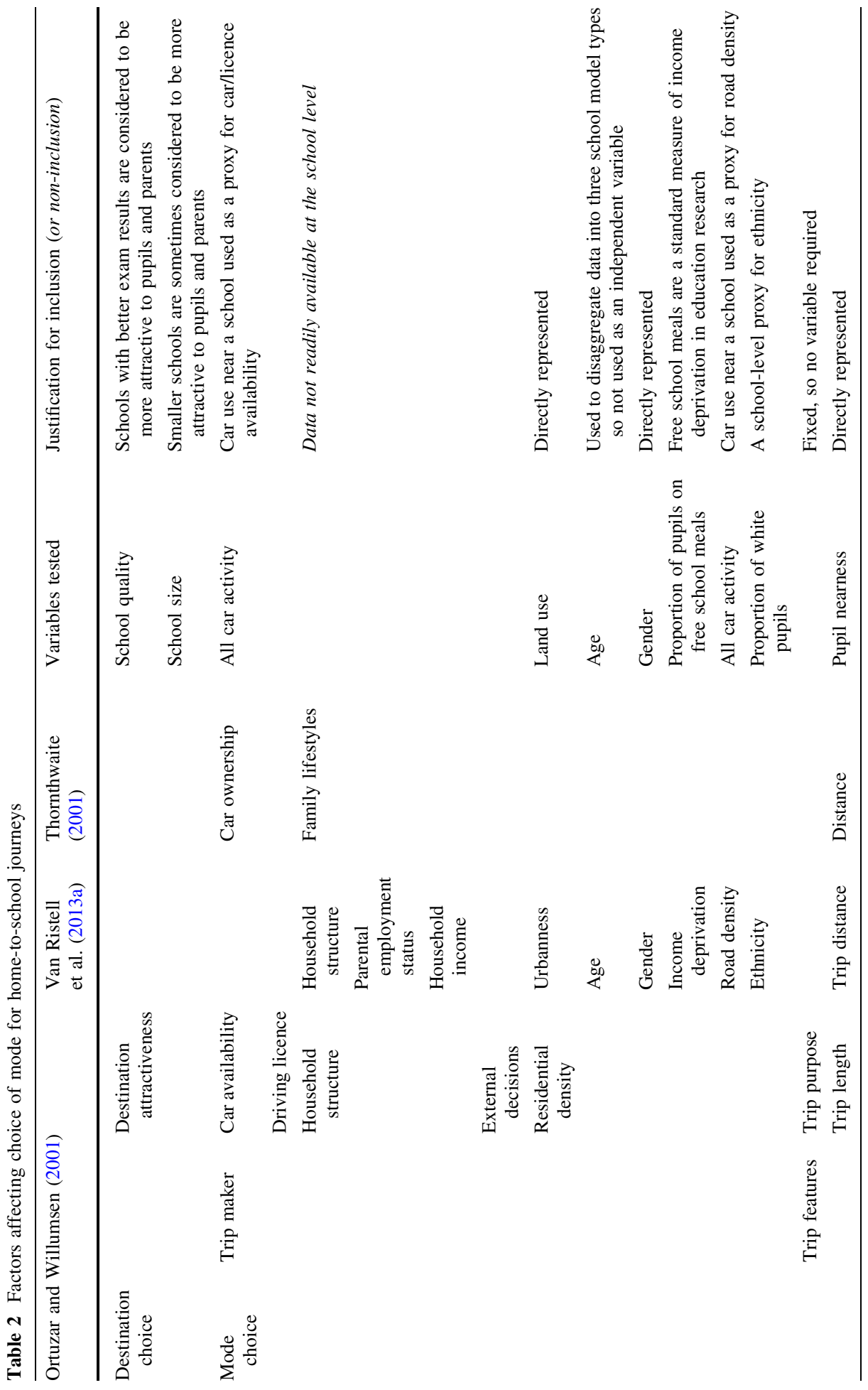




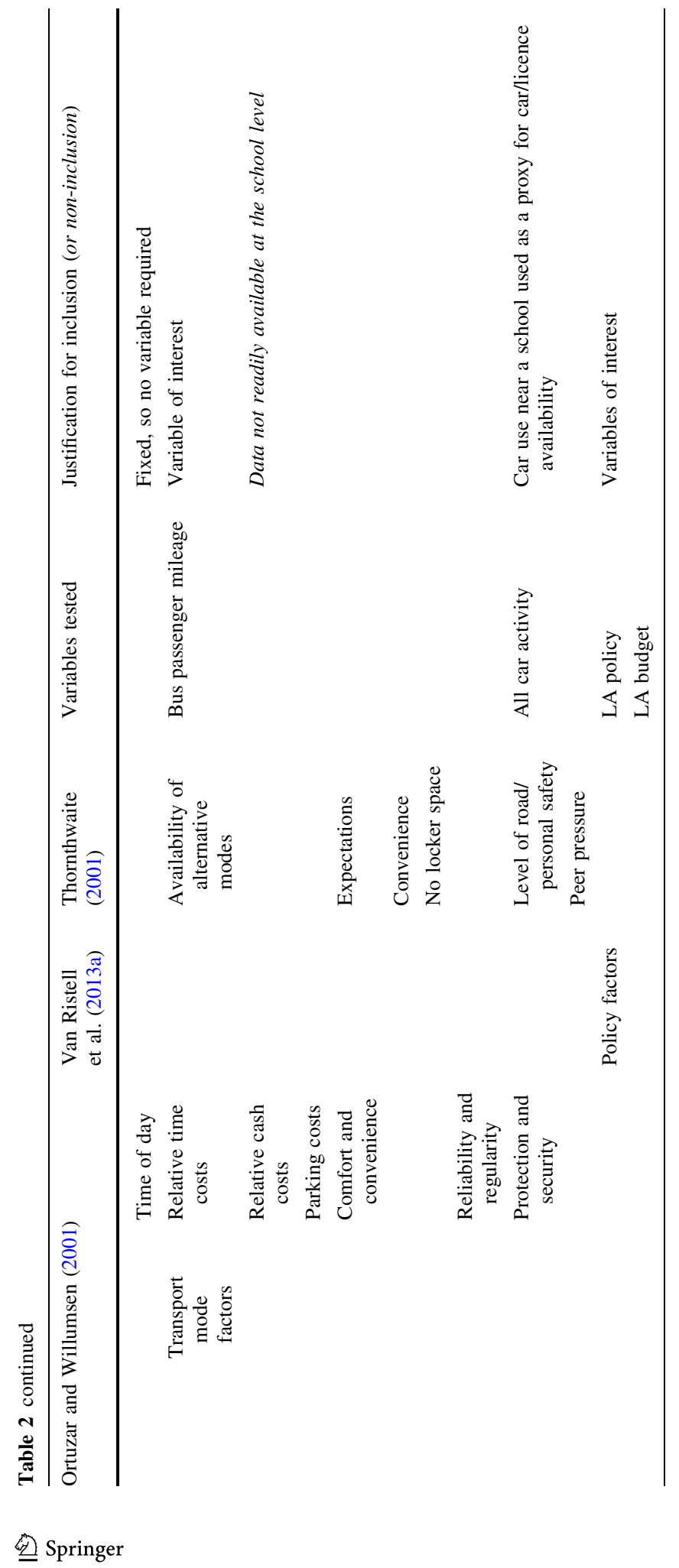




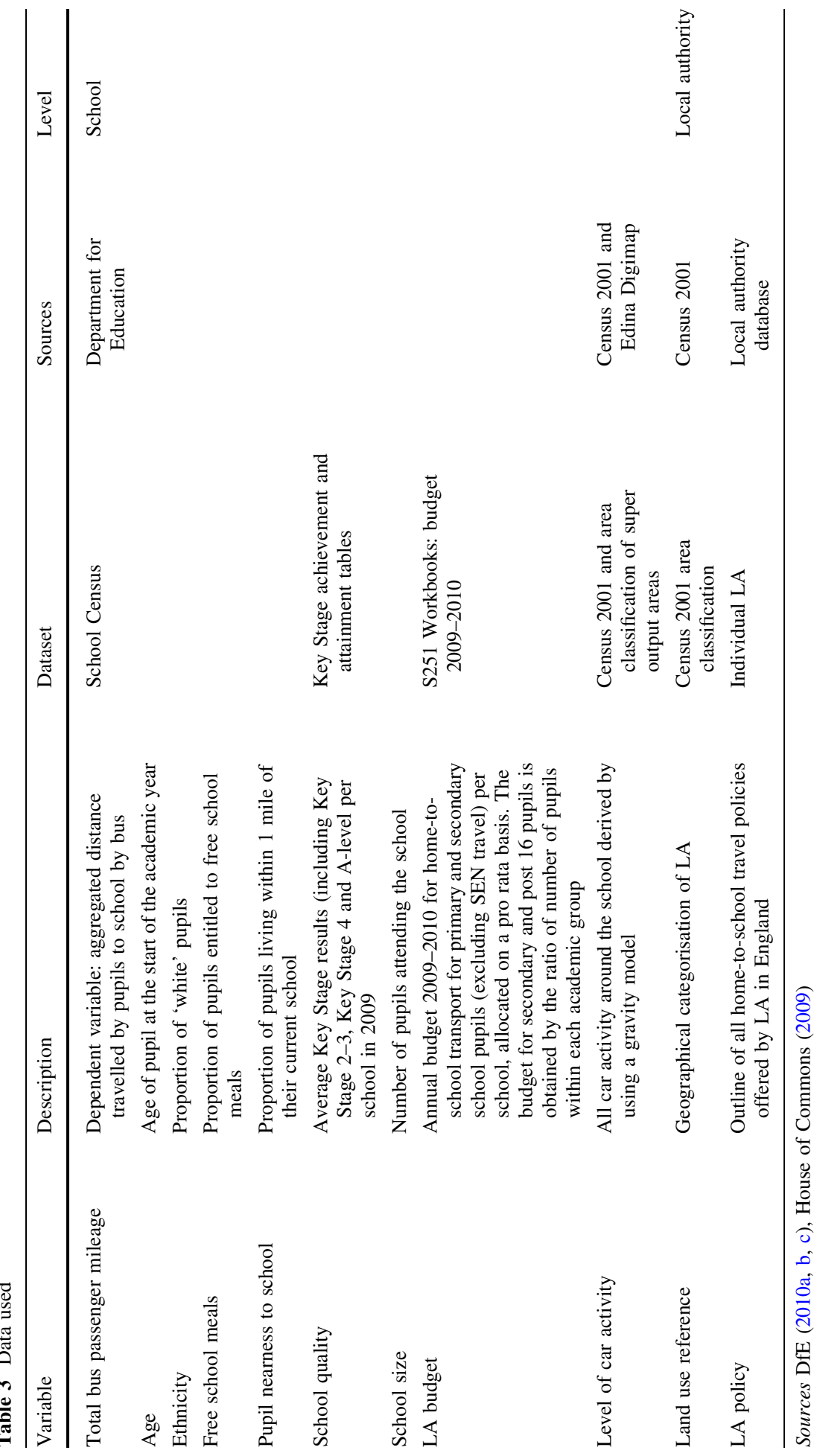


Total pupil miles travelled by bus for a school $=\sum_{k=1}^{K}$ BusPassengerDistance $_{k}$

in which $K$ refers to the number of pupils of the school who use 'buses' for home-to-school trips; BusPassengerDistance is the trip distance for each pupil $k$ who uses a bus to get to school from home in that school. Data for $K$ and BusPassengerDistance are obtained from School Census 2009. The average bus pupil mileage (or pupil-mile travelled by bus) by school is found to be 25 for primary, 755 for secondary and 115 for post 16 schools (see Table 3). At this point it should be noted that there is an argument for indexing the dependent variable to be bus mileage per pupil. However, it was felt that including school size as a control variable was perhaps slightly more theoretically consistent with the underpinning structure of the multi-level model, and so this was not applied.

Next, the explanatory variables age, ethnicity, and free schools meals (used as a proxy for income) were used directly from the School Census 2009. Ethnicity was operationalised at the school level through the creation of the variable 'percentage of white pupils' i.e. the number of white pupils divided by the total number of pupils multiplied by 100 . The variable 'age' was used to disaggregate School Census data into three school types (i.e. primary, Secondary and Post-16) and so was not used as an explanatory variable in the model. In converting the distances travelled to school by individual pupils into a meaningful school level variable, it was decided to measure the proportion of journeys under a particular value. One mile was chosen instead of other distance bands because previous evidence, such as Marshall et al. (2010), found that when a child's school is close to home the likelihood that they will walk increases, but "the odds of walking decline rapidly at longer travel distances: for travel distances greater than $1.6 \mathrm{~km}$ [i.e. one mile]" (p. 1540). Moreover, Van-Ristell et al. (2013a) drew on data from the English 2009 School Census to note that the average distance of pupils from home to current school was 1.3 miles, providing further support for the adoption of the one mile limit.

Further details regarding school size and school (such as location and academic achievement) were obtained from the Department for Education Key Stage Achievement Tables (DfE 2010c) provide details on the exam performance of schools at ages 10, 16 and 18 and in this paper the average grade achieved by school is used as a proxy for school quality.

Finally, the so-called S251 Workbooks (also from the DfE) were used to provide details of the 2009-2010 annual home-to-school transport budgets of LA for both SEN and nonSEN travel (DfE 2010a). For the purpose of this study only non-SEN travel and budget have been included. One of the primary variables in the analysis is the local authority budget that is allocated for home-to-school public transport provision and subsidies. From the budget data presented in Table 2, the average spending per bus user by local authority is calculated. Therefore, a variable-LA budget by school is calculated by multiplying the average spending by a LA for a bus user per year with the total number of bus users of the school (as reported by the School Census). Crucially, 'total bus users per school' is actually total bus users per school that are currently eligible for free travel [emphasis added], which we calculate in the model, and so this should not be underestimated.

The number of passenger cars registered within a school's neighbourhood (or car activity around a school) may also affect the level of pupil-miles travelled by bus. This can be achieved by summing up the registered cars within the Lower Layer Super Output Area (LLSOA) where the school is located and all other cars registered in the neighbouring LLSOAs weighted by the inverse of the centre-to-centre distance. A gravity model (see 
Eq. 7) can therefore be employed to obtain the total number of registered cars that may travel in a LLSOA (where the school is located) from its neighbouring LLSOAs:

$$
\text { Registered cars from the neighbouring LLSOAs }=\sum_{m=1}^{M} \frac{\mathrm{Car}_{m}}{D_{l m}} \quad l \neq m
$$

in which $\mathrm{Car}_{m}$ is the total number of cars registered in LLSOA $m$ which is neighbour to LLSOA $l$ where a school is located $D_{l m}$ is the Euclidean distance (miles) between LLSOA $l$ and $m ; M$ is the total number of neighbouring LLSOAs. The variable 'car activity' is intended to relate to car ownership levels and use (and indirectly to levels of congestion around the school) - the thought being that high traffic levels might make using the car a less attractive option than otherwise. It can also be thought as being a proxy for variables relating to car ownership and availability, road density, the availability of alternative modes, and to the perceived and actual level of road safety near a school.

At the local authority level, the land use reference variable was determined in a relatively crude way based on the type of local authority structure in place, although this was felt to be appropriate given the link to how policy is delivered. Thus, 'Rural' authorities were County Council areas; 'Urban' were non-metropolitan Unitary Authority districts; 'Metropolitan' were Unitary Boroughs in the former Metropolitan County Council areas (i.e. Tyne and Wear, West Yorkshire, South Yorkshire, Greater Manchester, Merseyside and West Midlands); 'Outer London' referred to the London Boroughs of Barking and Dagenham, Barnet, Bexley, Brent, Bromley, Croydon, Ealing, Enfield, Harringey, Harrow, Havering, Hillingdon, Kingston upon Thames, Merton, Newnham, Redbridge, Richmond upon Thames, Sutton and Waltham Forest; and 'Inner London' the remaining London Boroughs.

Second, as noted earlier, two categories of the 'LA policy' variable were created based on a review of local authority internet sites, namely 'Generous' and 'Standard'. Essentially, two dimensions were taken into account. First is whether any subsidy is restricted to certain groups (in this case via a distance criterion) or not, and second is the level/type of discount provided. Thus, LA which presented a significant discount of some form to all pupils (i.e. travel which was either discounted to half or less than a full commercial fare, or a bus pass costing less than $£ 100$ per annum, or a single bus fare costing less than $£ 1$ ) would be classed as being Generous. Meanwhile authorities that either only meet the statutory minimum requirements i.e. where free travel is offered only to pupils who attend their nearest school which is more than 2 miles (for primary pupils) or 3 miles (for secondary/ post 16 pupils) from home; or else have less charitable conditions than were classed as Standard. Interestingly, there are a number of examples of authorities offering 'generous' policies to encourage sustainable travel to school above the required home-to-school transport provision in spite of the current economic climate. For example, Transport for London (TfL) an external Government body funds and offers all pupils living within London unlimited free travel on all public transport in Greater London including bus services, underground services and rail services when travelling with a photo smartcard (TfL 2008).

Table 4 presents data relating to policy and spending distributions made by LA. For interest, it can be seen that the average amount spent by LA on all school bus subsidies combined in $2009 / 10$ was approximately $£ 2.8 \mathrm{~m}$, but that this amount ranged from a mean of only $£ 31,000$ for inner London authorities to a mean of almost $£ 9.6 \mathrm{~m}$ for rural authorities. Meanwhile the average spent on secondary school bus transport accounted for 


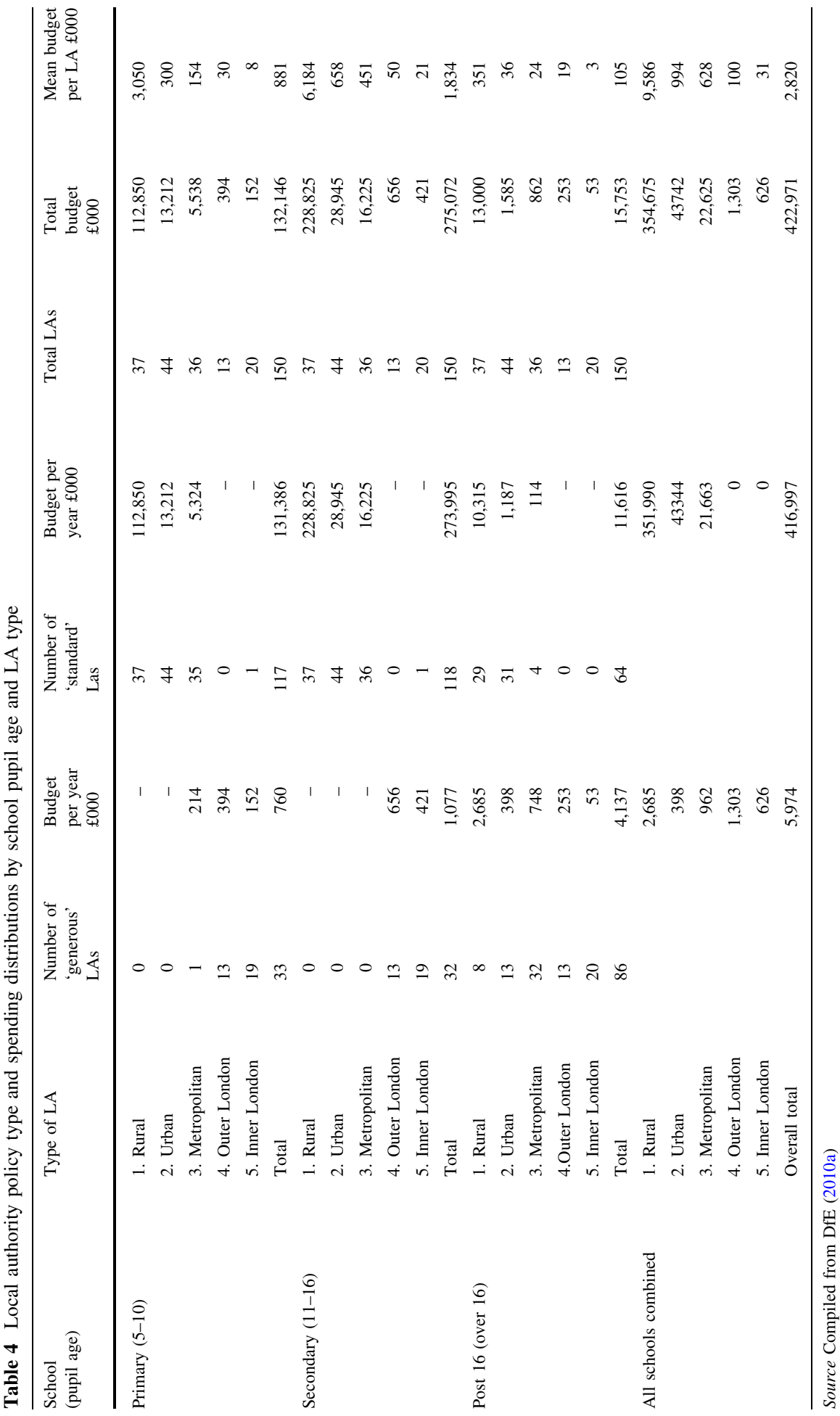


$£ 1.8 \mathrm{~m}$ of the $£ 2.8 \mathrm{~m}$ figure, around double that of spending on primary schools $(£ 880,000)$ and significantly more than that spent on post 16 provision $(£ 105,000)$.

At this point, it should be noted that the model was developed without London schools and LA. This was because the London LA are located within the area covered by TfL which has offered in recent years free travel for schoolchildren on the public bus network (see above). The London LA budgets for school transport thus relate very largely to SEN pupils, and are not directly comparable with the situation elsewhere in England. This affected the results because the London LA would have a high proportion of children travelling by bus with minimal funding. For this reason London LA were excluded from the analysis. Hence LA (without London) were divided into three categories such as rural, urban and metropolitan so as to capture the impact of land-use pattern on school-level pupil bus mileage. Due to correlation, other variables from the School Census 2009 data including gender and car ownership have also been excluded from the model. Table 5 shows the variables considered in the models and their summary statistics.

\section{Model estimation results}

A series of multilevel regression models were estimated for different age groups (such as primary school aged less than 11 , secondary school aged from 11 to 16 and post 16 aged 17 years and above). The log-likelihood ratio test was used to identify the best model and the results indicate that a mixed-effect model outperforms a random-intercept model in all cases. All possible combinations of cross-level interaction terms were considered and only statistically significant interaction terms were retained.

The dependent variable-school-level pupil-mile travelled by bus-was transformed into a logarithmic scale as this variable should be non-negative and hence this transformation would avoid the potential problem of obtaining a negative predicted value in the dependent variable.

In order to reduce the variance among the variables, school size was also transformed into a logarithmic scale and LA budget by school was divided by 1,000. The model estimation results are presented in Table 6. The interpretations of various explanatory variables are presented.

An investigation was carried out as to see why there are missing observations in the data sets. It was found that the only significant variable with missing values was school quality, and that no clear pattern was observed suggesting that missing observations are not likely to impact the estimation results. Specifically, the percentage of missing values for Primary Schools was $33 \%$, for Secondary Schools was $18.5 \%$ and for Post 16 Schools was $23 \%$. The model's goodness-of-fit (GOF) measured by the Pseudo R-squared is found to be very good (ranging from 0.19 to 0.31 ), especially for the models related to secondary and post 16 schools where LAs are currently spending the majority of their budget.

As shown in Table 6 the intra-class correlation coefficients estimated in different models ranges from 0.33 to 0.46 suggesting that school-level factors explain over $30 \%$ variation in total pupil bus mileage. This means that the differences in characteristics between higher level groups (such as LA) are relatively significant and LAs differ from each other. The variable-percentage of pupils eligible for free school meals-is excluded from the secondary schools model as this variable has found to be highly correlated with the school quality variable and the inclusion of this variable affects the results of other parameter estimates. This is however not the case for the other two models. 
Table 5 Summary statistics of variables to be used in the models

\begin{tabular}{|c|c|c|c|c|c|}
\hline Variable & Observation & Mean & Std. dev. & Min & $\operatorname{Max}$ \\
\hline \multicolumn{6}{|l|}{ Primary school pupils } \\
\hline $\begin{array}{l}\text { Total school-level pupil-miles travelled by } \\
\text { bus for single home-to-school trip }\end{array}$ & 11,803 & 25.1551 & 57.5410 & 0 & $1,861.08$ \\
\hline $\begin{array}{l}\text { Percentage of pupils entitled to free school } \\
\text { meals }\end{array}$ & 11,819 & $17.2,328$ & $14.4,203$ & 0 & 100 \\
\hline Percentage of white pupils & 11,819 & $75.8,263$ & $27.5,755$ & 0 & 100 \\
\hline $\begin{array}{l}\text { Percentage of pupils living within } 1 \text { mile of } \\
\text { school }\end{array}$ & 11,819 & 72.4539 & 23.9187 & 0 & 100 \\
\hline All car activity around school & 9,845 & 934.5879 & 246.4843 & 343.0274 & $2,309.482$ \\
\hline Number of pupils at school & 11,819 & 248.6218 & 138.137 & 1 & 972 \\
\hline Average Key Stage 2 results & 9,107 & 27.7146 & 2.20540 & 15 & 32.7 \\
\hline LA budget by school & 11,819 & $11,466.95$ & $30,082.12$ & 0 & $905,873.3$ \\
\hline Schools in LA with a generous policy & 2,053 & 0.1737 & 0.3789 & 0 & 1 \\
\hline Schools in LA with a standard policy & 9,733 & 0.8263 & 0.3789 & 0 & 1 \\
\hline Rural schools & 5,289 & 0.4475 & 0.4973 & 0 & 1 \\
\hline Urban schools & 1,740 & 0.1472 & 0.3543 & 0 & 1 \\
\hline Metropolitan schools & 2,999 & 0.2537 & 0.4358 & 0 & 1 \\
\hline \multicolumn{6}{|l|}{ Secondary school pupils } \\
\hline $\begin{array}{l}\text { Total school-level pupil-miles travelled by } \\
\text { bus for single home-to-school trip }\end{array}$ & 4,000 & 755.3125 & 996.6127 & 0.26 & $8,846.09$ \\
\hline $\begin{array}{l}\text { Percentage of pupils entitled to free school } \\
\text { meals }\end{array}$ & 5,345 & 18.4174 & 22.0891 & 0 & 100 \\
\hline Percentage of white pupils & 5,345 & 82.1128 & 26.6125 & 0 & 100 \\
\hline $\begin{array}{l}\text { Percentage of pupils living within } 1 \text { mile of } \\
\text { school }\end{array}$ & 5,345 & 44.9370 & 32.1744 & 0 & 100 \\
\hline All car activity around school & 3,935 & 942.4066 & 210.4412 & 344.5559 & $1,871.117$ \\
\hline Number of pupils at school & 4,001 & 755.4501 & 462.5329 & 1 & 2,404 \\
\hline Average GCSE results & 3,243 & 0.4682 & 0.23090 & 0 & 1 \\
\hline LA budget by school & 4,001 & $68,332.92$ & $108,047.6$ & 0 & $851,856.9$ \\
\hline Schools in LA with a generous policy & 578 & 0.1445 & 0.3516 & 0 & 1 \\
\hline Schools in LA with a standard policy & 3,423 & 0.8555 & 0.3516 & 0 & 1 \\
\hline Rural schools & 1,951 & 0.4876 & 0.4999 & 0 & 1 \\
\hline Urban schools & 627 & 0.1567 & 0.3636 & 0 & 1 \\
\hline Metropolitan schools & 872 & 0.2179 & 0.4129 & 0 & 1 \\
\hline \multicolumn{6}{|l|}{ Post 16 pupils } \\
\hline $\begin{array}{l}\text { Total school-level pupil-miles travelled by } \\
\text { bus for single home-to-school trip }\end{array}$ & 2,008 & 115.7528 & 161.1366 & 0.33 & $2,432.62$ \\
\hline $\begin{array}{l}\text { Percentage of pupils entitled to free school } \\
\text { meals }\end{array}$ & 2,326 & 9.3868 & 14.8718 & 0 & 100 \\
\hline Percentage of white pupils & 2,326 & 79.3870 & 25.1453 & 0 & 100 \\
\hline $\begin{array}{l}\text { Percentage of pupils living within } 1 \text { mile of } \\
\text { school }\end{array}$ & 2,326 & 33.4914 & 23.1552 & 0 & 100 \\
\hline All car activity around school & 2,007 & 961.0058 & 204.7189 & 400.8833 & $1,803.596$ \\
\hline Number of pupils at school & 2,008 & 87.0757 & 62.7913 & 1 & 685 \\
\hline Average GCSE results & 1,541 & 197.9694 & 21.5181 & 50.2 & 256.3 \\
\hline
\end{tabular}


Table 5 continued

\begin{tabular}{lcllll}
\hline Variable & Observation & Mean & Std. dev. & Min & Max \\
\hline LA Budget by School & 1,979 & $21,325.75$ & $51,160.59$ & 0 & $693,485.4$ \\
Schools in LA with a generous policy & 994 & 0.4950 & 0.5001 & 0 & 1 \\
Schools in LA with a standard policy & 957 & 0.4765 & 0.4996 & 0 & 1 \\
Rural schools & 999 & 0.4975 & 0.5001 & 0 & 1 \\
Urban schools & 282 & 0.1404 & 0.3475 & 0 & 1 \\
Metropolitan schools & 423 & 0.2107 & 0.4079 & 0 & 1 \\
\hline
\end{tabular}

Table 6 Multilevel modelling results

\begin{tabular}{|c|c|c|c|c|c|c|}
\hline \multirow[t]{2}{*}{ Multi-level (ML) modelling results } & \multicolumn{2}{|l|}{ Primary } & \multicolumn{2}{|l|}{ Secondary } & \multicolumn{2}{|l|}{ Post 16} \\
\hline & Coefficient & t-stat & Coefficient & t-stat & Coefficient & t-stat \\
\hline \multicolumn{7}{|l|}{ Bus passenger mileage-dependent variable } \\
\hline \multicolumn{7}{|l|}{ School-level variables } \\
\hline $\begin{array}{l}\text { Percentage of pupils entitled to free school } \\
\text { meals }\end{array}$ & 0.0049 & 4.54 & - & - & 0.0007 & 0.16 \\
\hline Percentage of white pupils & 0.0007 & 1.16 & 0.0075 & 4.42 & 0.0045 & 2.65 \\
\hline $\begin{array}{l}\text { Percentage of pupils living within } 1 \text { mile of } \\
\text { school }\end{array}$ & -0.0189 & -13.97 & -0.0206 & -9.38 & -0.0219 & -9.09 \\
\hline All car activity around school & -0.00002 & -0.46 & -0.0001 & -0.98 & 0.0001 & 0.84 \\
\hline $\log ($ school size $)$ & -0.0535 & -1.64 & 0.2139 & 2.66 & 0.5295 & 5.43 \\
\hline School achievement & -0.0103 & -1.78 & 0.6525 & 7.37 & 0.0035 & 2.71 \\
\hline LA budget by school in thousand & 0.0716 & 1.61 & 0.0083 & 7.51 & 0.0297 & 7.5 \\
\hline \multicolumn{7}{|l|}{ Local authority-level variables } \\
\hline $\begin{array}{l}\text { LA fare policy (standard }=1 \text {, } \\
\quad \text { generous }=0 \text { ) }\end{array}$ & -0.6129 & -1.63 & -0.0889 & -0.19 & 0.2509 & 1.87 \\
\hline Urban area & -0.4549 & -4.61 & -0.658 & -5.32 & -0.427 & -2.97 \\
\hline Metropolitan area & -0.5738 & -5.66 & -0.5317 & -4.2 & -0.238 & -1.44 \\
\hline \multicolumn{7}{|l|}{ Rural (reference) } \\
\hline \multicolumn{7}{|l|}{ Interaction terms } \\
\hline $\begin{array}{l}\text { Percentage of pupils living within } 1 \text { mile of } \\
\text { school } \times \text { urban }\end{array}$ & - & - & - & - & -0.0056 & -1.67 \\
\hline $\begin{array}{l}\text { Percentage of pupils living within } 1 \text { mile of } \\
\text { school } \times \text { metro }\end{array}$ & - & - & - & - & -0.0093 & -2.98 \\
\hline $\log ($ school size $) \times$ urban & 0.2437 & 4.13 & 0.1584 & 1.43 & -0.0071 & -1.61 \\
\hline $\log ($ school size $) \times$ metro & 0.2761 & 5.52 & 0.5024 & 4.59 & -0.012 & -3.21 \\
\hline LA budget by school $\times$ urban & 0.1406 & 2.3 & 0.0036 & 2.01 & 0.2389 & 1.43 \\
\hline LA budget by school $\times$ metro & 0.5348 & 7.53 & 0.0118 & 4.24 & 0.2519 & 1.71 \\
\hline \multicolumn{7}{|l|}{ Random parameters } \\
\hline $\begin{array}{l}\text { Standard deviation of percentage of } \\
\text { white pupils }\end{array}$ & - & - & 0.0089 & 4.14 & - & - \\
\hline $\begin{array}{l}\text { Standard deviation of percentage of pupils } \\
\text { living within } 1 \text { mile of school }\end{array}$ & 0.0108 & 8.79 & 0.0093 & 6.24 & 0.01 & 4.38 \\
\hline standard deviation of $\log$ (school size $)$ & 0.1002 & 2.75 & 0.3905 & 9.25 & 0.38 & 5.86 \\
\hline Standard deviation of LA budget & 0.2763 & 9.13 & 0.0061 & 5.67 & 0.03 & 5.01 \\
\hline
\end{tabular}


Table 6 continued

\begin{tabular}{|c|c|c|c|c|c|c|}
\hline \multirow[t]{2}{*}{ Multi-level (ML) modelling results } & \multicolumn{2}{|l|}{ Primary } & \multicolumn{2}{|l|}{ Secondary } & \multicolumn{2}{|l|}{ Post 16} \\
\hline & Coefficient & t-stat & Coefficient & t-stat & Coefficient & t-stat \\
\hline Intercept $\mathrm{SD}\left(\mathrm{u}_{0}\right)$ & 0.4133 & 13.49 & 0.5041 & 12.39 & 0.5079 & 9.36 \\
\hline Error SD $(\varepsilon)$ & 0.7108 & 113.30 & 0.6876 & 66.88 & 0.6972 & 42.78 \\
\hline \multicolumn{7}{|l|}{ Statistics } \\
\hline Pseudo R-square & 0.48 & & 0.49 & & 0.44 & \\
\hline Log-likelihood at convergence & $-8,002.73$ & & $-3,319.06$ & & $-1,627.67$ & \\
\hline Observations & 6,901 & & 2,808 & & 1,309 & \\
\hline Number of groups & 114 & & 114 & & 106 & \\
\hline Intra-class coefficient & 0.3375 & & 0.4625 & & 0.455 & \\
\hline
\end{tabular}

There is much variation in the results over the three age groups. Looking first at primary schools, most of the results are negative meaning that the variables move in opposite directions or when one variable changes the other does not. Only School Size and LA Budget by School show a positive relationship for primary schools. For older pupils, the only positive relationship is between Pupil Location and LA Budget suggesting that the variables do not influence each other.

As expected, factors affecting school-level pupil mileage are different for different schools. For instance, the percentage of white pupils has found to be statistically and positively significant in the secondary and post 16 but insignificant in the primary schools model. School achievement is also only found to be statistically significant for secondary and post 16 schools. This variable is negatively associated with the total pupil mileage for the case of primary schools, but is positively associated with the total pupil bus-mileage in the other two models. LA-level land-use variables also show a mixed-effect on pupil mileage.

Some of the controlling variables such as school size and pupils living within 1 mile from the school have shown the expected effect on the total pupil bus-mileage. Hence, across all age groups, the more pupils that live within 1 mile of their school travel less by bus, likely due to many alternate modes of travel being available (such as walking and cycling). At primary school age, the more pupils who receive free school meals from the Government are more likely to use the bus in their journey to school. The average grade achievement of a school for secondary school and post 16 pupils could be the result of these grades having more impact on later life and therefore pupils are more willing to travel further to reach the schools with higher exam achievement.

Geographical factors have a considerable impact on bus usage for pupils. In the case of primary school pupils, this can be due to parents having concerns regarding the safety of young children travelling alone to school which is not unusual. Older children however, are more likely to use the bus in their journey to school when living in a rural area as oppose to more dense urban and metropolitan areas. It is likely this is because schools are generally more accessible via walking and cycling in urban and metropolitan areas.

One of the key findings of this study is that LA budget is highly statistically significant in the secondary and post 16 models but only marginally significant in the primary school models. The results suggest that the higher an LA budget, the more pupil bus-mileage expected from a school. Since the dependent variable (the total school-level pupil-miles 
Table 7 Elasticity of pupil busmileage with respect to LA budget

\begin{tabular}{llll}
\hline LA location & Primary & Secondary & Post 16 \\
\hline Rural & 0.12 & 0.10 & 0.13 \\
Urban & 0.37 & 0.15 & \\
Metro & 1.04 & 0.26 & \\
\hline
\end{tabular}

travelled by bus for single home-to-school trip) was transformed into a logarithmic scale, one needs to carefully quantify the effect of explanatory variables on school-level bus usage. Accordingly, the elasticity of pupil bus-mileage with respect to LA Budget is estimated from the developed models and the results are presented in Table 7.

As expected, each of the models is slightly different in terms of the sets of statistically significant variables and their associations with the dependent variable. Looking first at primary schools, most of the statistically significant explanatory variables are negatively related to the dependent variable (i.e. school-level bus mileage), the only exceptions being percentage of pupils entitled to free school meals and the cross-level interaction terms. Meanwhile the secondary and post-16 models are largely consistent with each other but different to the primary model in that School Size and School Achievement are positive in both cases. However, one exception between the secondary and post-16 models is that the variable $L A$ fare policy is insignificant for secondary schools but positively significant for post-16 (whilst being marginally negatively associated for the primary model).

Meanwhile another finding shown in Table 7 is that elasticities apparently increase as the level of urbanisation increases. One explanation here could be that pupils have fewer travel options in rural areas compared with their contemporaries in towns and particularly in larger cities meaning that they are less sensitive to changes in subsidies. Support for that suggestion is provided by a further analysis of the School Census data in Table 8, illustrating the average journey lengths for pupils using buses in metropolitan, urban and rural locations. These show that average journey lengths increase from 1.40 miles for metropolitan primary school trips to 1.57 miles (urban primary school trips) and 1.99 miles (rural primary school trips), whilst the same pattern is also extant for both the secondary and post 16 cases. Similarly, bus journey lengths increase as pupils progress from primary, to secondary, and post 16 schools in all location types.

Turning next to the distributions of these journey lengths across all location types, $30 \%$ of primary school bus trips are less than 1.04 miles (which might be considered to be a reasonable walking distance for a 5-10 year old child) and $90 \%$ are less than 3.04 miles (reasonable cycling distance). Meanwhile the corresponding figures for secondary school pupils are 1.99 and 5.51; and for post 16 are 2.46 and 6.50-again, distances that are not unimaginable for older children to walk and to cycle. However, in practice it is likely that 'other reasons' (see Van-Ristell et al. 2013b) may well result in a significant proportion of these trips still being undertaken by car, hence the assumption behind the calculations made later in this paper.

The next stage of this study involved estimating the changes in pupil-mile travelled by bus that would occur if LA removed their bus provision policy in order to save significant sums of money. First of all, models presented earlier in Table 6 estimated the total pupilmile travelled by bus in England for each of the school categories. In the next step, LA budget by school was assumed to be zero (if no budget is available for home-to-school public transport provision and the dummy variable for bus fare provision is statistically insignificant) and models with the coefficient for LA budget by school $=0$ were then used to re-estimate the total pupil-mile travelled by bus in England for each of the school 
Table 8 Average bus-mileage journey lengths with respect to LA budget

\begin{tabular}{llll}
\hline LA location & Primary & Secondary & Post 16 \\
\hline Rural & 1.40 & 2.32 & 2.68 \\
Urban & 1.57 & 2.71 & 3.78 \\
Metro & 2.68 & 3.58 & 4.36 \\
\hline
\end{tabular}

categories (these are also presented in Table 6). In all cases, the total re-estimated pupilmile travelled by bus was less than the total pupil-mile travelled by bus estimated earlier with the inclusion of the

budget variable. The results suggest that if the LA budget is reduced to zero, schoollevel pupil-mile travelled by bus in England would decrease by 2, 11 and $11 \%$ for primary, secondary and post 16 schools respectively.

According to the School Census data, given that the average bus passenger mileage for the primary, secondary and post 16 pupils are 1.83, 3.12 and 5.73 respectively, then this decrease in bus passenger mileage may result in the reduction of bus trips as some of the pupils would change their mode of travel (such as bus to car or other modes). In other words, 2,517 primary school pupils (from a total of 125,842 based on the School Census), 103,045 secondary school pupils (from a total of 936,770) and 6,686 post 16 pupils (from a total of 60,782) may look to travel in other ways which may result in more congestion during peak travel times if the home-to-school subsidy provision was removed. For pupils to change from using the bus this could lead to 112,200 pupils travelling twice a day (190 school days per year) resulting in almost 140 million miles a year potentially being made by less sustainable modes of travel at peak times and often in urbanised areas, and thus leading to further congestion and environmental issues around England (see Table 9).

However, this analysis is not necessarily the full story. This is because it assumes that the existing supply of bus services would remain in place should the subsidy be removed. In reality though, it is likely that a fairly significant proportion of services would no longer be financially viable and so would be withdrawn, therefore potentially leading to a series of knock on effects leading to reductions in bus service provision and use more generally. Such an outcome would, for example, be particularly pronounced in local authority areas such as Wiltshire, where subsidised bus services have for many years been built around (and effectively subsidised by) the education transport trip budget.

\section{Discussion}

In discussing the implications of this research, the policy choice to be made balances the idea that the current approach not only represents a significant financial cost in straightened times, but is based on assumptions of how people travelled 70 years ago, against the principle that properly managed bus subsidies can actually be a highly effective means of delivering broader societal benefits. In untangling this, the following thoughts emerge.

First is that the 'one size fits all' approach is no longer sufficient. The option of a bus service provided twice a day at $8 \mathrm{a} . \mathrm{m}$. and $3.30 \mathrm{p} . \mathrm{m}$. is not now particularly attractive in a world where both parents work for example.

Second, the dominant policy objective in 1944 was to ensure that pupils could access education. However, whilst still important, other issues too have arisen, not least children's safety, health, and independence, as well as mitigating traffic congestion and air pollution. 
Table 9 Shift in pupil mileage if LA budget $=0$

\begin{tabular}{lccllr}
\hline $\begin{array}{l}\text { School } \\
\text { type }\end{array}$ & $\begin{array}{l}\text { Total } \\
\text { pupil } \\
(\mathrm{A})\end{array}$ & $\begin{array}{l}\text { Affected pupils if } \\
\text { LA budget }=0(\mathrm{~B})\end{array}$ & $\begin{array}{l}\text { Average pupil bus } \\
\text { mileage per trip (C) }\end{array}$ & $\begin{array}{l}\text { Total trips per } \\
\text { year per pupil } \\
(\mathrm{D})\end{array}$ & $\begin{array}{l}\text { Total pupil } \\
\text { mileage } \\
(\mathrm{B} \times \mathrm{C} \times \mathrm{D})\end{array}$ \\
\hline Primary & 125,842 & 2,517 & 1.83 & $190 \times 2=380$ & $1,750,211$ \\
Secondary & 936,770 & 103,045 & 3.12 & $190 \times 2=380$ & $122,169,796$ \\
Post-16 & 60,782 & 6,686 & 5.73 & $190 \times 2=380$ & $14,558,140$ \\
\multicolumn{7}{l}{ Total annual shift in pupil mileage from bus if LA budget $=0$} & & $138,478,147$ \\
\hline
\end{tabular}

Moreover, with these in mind, one might argue that the current distance-based criteria could be said to incentivise people to live further from school than they otherwise might, making it less likely that they will travel by sustainable modes.

Third, on the other hand it should be noted that the current home-to-school subsidy regime is of vital importance in several rural local authority areas (e.g. Wiltshire), because the education transport budget effectively funds much of the core subsidised bus network across the County. Thus, the removal of this revenue stream could potentially have a significant impact on bus provision in some areas that is far broader than just pupils travelling to and from school.

Overall, in transport policy terms whilst there is a case for focusing resources on mitigating the impacts of the school run, the current approach of subsidising bus travel for pupils living more than 2 or 3 miles from their nearest school is not always appropriate. Instead, a more flexible (and probably more equitable) system would be to allocate these resources towards enhancing so-called school travel plans (either via LA or direct to local networks of schools). Such a policy, whereby 'packages' of transport and other measures (which may include subsidising buses in some cases) would be developed to meet the specific access needs of each pupil attending those schools, has already begun to be adopted in the UK, but there is scope for this approach to be applied more systematically and effectively (see Enoch 2012), Also important, is a recognition that recent policy decisions seemingly indicate that transport impacts are generally largely ignored when 'bigger' policy decisions are taken, such as those aimed at increasing choice for parents in deciding which school their children should attend for example (see Van-Ristell et al. 2013b). Unless this reality changes then it is likely that transport planners will continue to face significant challenges in getting children to and from school.

In looking beyond the policy context, and instead considering the overall approach taken in the paper, one point to reflect on is the so-called 'endogeneity' argument. This suggests that because budgets are dependent on the need for travel (measured here in 'pupil bus miles'), then the logic underlying the paper (which assumes that the need for travel is instead dependent on subsidy) is somehow back to front. However, whilst it is true that in the current situation then clearly budgets now are dependent on the need for travelbecause there is a formula set by the current policy which dictates that ' $x$ ' number of pupils qualify for a particular level of bus service/subsidy which will cost an amount ' $y$ '. The point of this paper is to explore what would happen should the policy that underlies this current situation be altered, in which case the available level of subsidy would influence how much travel need could be met. This, it is argued, is a reasonable assumption to make, given the response referred to in the Introduction by several UK LA to the budget cuts of October 2010, whereby in the most extreme cases Hartlepool, Cambridgeshire and Northamptonshire all announced that they were to withdraw all subsidies from non- 
commercial bus routes in their areas which they had previously supported. Meanwhile other councils too, such as Leicestershire, entirely revamped their supported bus networks in light of the reduced budgets provided to them by central Government. In such cases then, the level of subsidy has very forcefully dictated the travel needs to be met, and it can therefore be argued that such a situation may well be applied to the school bus sector at some point, in which case it would be useful to understand how this would affect the resultant pupil travel patterns.

One limitation of the multi-level approach meanwhile, is that it was not possible to quantitatively explore the implications of such policy changes on individuals-e.g. how the removal of the bus subsidy would impact on the choice of school, or on the equity implications of such a policy_-because the levels modelled were local authority and school and not individual, and hence alternative approaches would need to be followed to consider these elements. On the other hand though, the multi-level model does allow correlation in school-level bus usages within each local authority, and hence this allowed the extent to which variation could be attributed to the school and local authority levels.

Finally, one key strength of this research is that it devises an approach which uses data that is readily available to policy analysts (be they in Government, consultancies or academia)_-making it relatively quick and inexpensive to carry out. However, the negative side to this pragmatic approach to data collection is that one or two variables that may have enhanced the performance of the model-for example household structure and household income-were not modelled.

\section{Conclusions}

In England, home-to-school transport provision comes at a cost of more than a billion pounds a year, of which just over half is spent on services for SEN children and so is difficult to reduce. Clearly, in such straightened financial times, this is a significant amount of money. Moreover, the policy has remained largely unchanged since it was introduced in 1944-when travel patterns and lifestyles more generally were very different to today. Consequently, this paper sought to examine and evaluate the policies relating to the funding criteria of home-to-school transport provision.

The initial policy review found that 119 LAs offer the standard statutory policy to primary and secondary school pupils in England, whilst 33 offer a more generous policy. However, 86 LAs offer post 16 pupils a more generous school transport policy even though they are not obliged by law to do so.

In this model it is assumed that pupil-bus-mileage levels by school would differ due to the explanatory variables modelled and this is evident in the results. For example, in the case of primary school pupils, school-based variables had less influence on school bus mileage than local authority variables. However, for both secondary and post 16 schools, school-related variables were more influential on school bus mileage than LA-variables.

In transport terms, the analysis found that if the home-to-school transport subsidy was removed, then LAs across England could see up to $2 \%$ of the state school population $(112,200$ pupils) switching their mode of travel from the bus to other modes. This would thereby potentially reduce the mode share of bus for education journeys from $15 \%$ currently to $13 \%$. Moreover, given the average one way trip length of these bus trips of 3.12 miles per pupil (DfE 2010b), travelling twice a day (190 school days per year), this could result in an additional 138 million vehicle miles a year potentially being made by less 
sustainable modes of travel and thus leading to further congestion and environmental issues around England.

While this represents only a small fraction of the 260 billion vehicle miles travelled annually, the fact is that these trips would likely occur at peak times, thus even minor fluctuations in demand could inevitably impact on road networks. More broadly, there are also implications for children's health, independence, the environment (or $\mathrm{CO}_{2}$ emissions) and traffic congestion, as well as for the financial viability of rural bus services. Fundamentally, policy makers need to make a judgement as to how effective this home-to-school transport subsidy is in cost benefit terms, when compared to other areas of public expenditure, and this paper provides some of the evidence base to allow them to do so. Specifically this paper is significant in that it helps to provide an indication of the degree to which reduced bus subsidies could generate extra car trips and in presenting a practicable methodology for policy makers across transport and broader topic areas to evaluate policy choices in a more robust manner than currently. Meanwhile the novelty stems from its application to the school travel sector, and in its use of a multilevel model that simultaneously identifies the significant factors related to school travel policy (at the local authority level), school quality (at the school level) and cross-level interaction terms.

Additionally, it should be noted that this paper is a development of work presented at two conferences, namely:

- Van Ristell, J. A. (2011) Modelling the effects of changing local authority funding criteria for home-to-school transport provision, Presented to the Universities Transport Studies Conference, University of Aberdeen, Aberdeen, 4-6 January (Winner of the Smeed Prize for Best Student Paper).

- Van Ristell J A, Quddus M A, Enoch M P, Wang C and Hardy P (2013c) Multilevel Modelling of Local Authority Funding Options Relating to Bus Provision for Home-toSchool Journeys in England. Poster presentation to the 92nd Annual Meeting of the Transportation Research Board, Paper 13-3614, Session 406, School Transportation Research: Safety and Human Factors, Committees of Transportation Safety Management, Occupant Protection and School Transportation, Transportation Research Board, National Academy of Science, 13-17 January, Washington, DC.

Acknowledgments This project is based on a PhD project entitled 'Investigating the impacts of policy on school travel' by Jessica Van Ristell which was funded by the Engineering and Physical Sciences Research Council (EPSRC) and JMP Consultants Ltd (Grant CASE/CAN/07/97). We are also grateful to the Department for Education (Great Britain) for providing access to the School Census dataset, and to Mr. Barney Newbould for his assistance in our research. Please contact the corresponding author if there are any questions regarding access to the dataset used.

Open Access This article is distributed under the terms of the Creative Commons Attribution License which permits any use, distribution, and reproduction in any medium, provided the original author(s) and the source are credited.

\section{References}

Abbott, I., Rathbone, M., Whitehead, P.: Education policy. Sage, London (2012)

Audit Commission: Going places: taking people to and from education, social services and healthcare, Audit Commission, London, 25 December (2001)

British Broadcasting Corporation (BBC): Spending Review 2010: Key Points At-a-Glance. http://www.bbc. co.uk/news/uk-politics-11591881 (2010). Accessed 20 Mar 2011 
Chantrill, C.: Total Planned Public Spending Expenditure Charts GDP Debt. http://www.ukpublicspending. co.uk/ (2011). Accessed 4 Jan 2013

Chen, D., Kallsen, H.A., Snider, R.C.: School bus routing and scheduling: an expert system approach. Comput. Ind. Eng. 15(1-4), 179-183 (1988)

Chowdry, H., Sibieta, L.: Trends in Education and Schools Spending, IFS Briefing Note BN121. Institute for Fiscal Studies, London (2011)

Cohen, J.T.: Diesel vs. compressed natural gas for school buses: a cost-effectiveness evaluation of alternative fuels. Energy Policy 33(13), 1709-1722 (2005)

Department for Education (DfE) (Great Britain): S251 Workbooks: Budget 2009-2010. http://www. education.gov.uk/b0069079/s251-workbooks-budget-2009-10/ (2010a). Accessed 17 June 2011

Department for Education (Great Britain): School Census 2009 (Only accessible on request) (2010b)

Department for Education (DfE) (Great Britain): Key stage achievement and attainment tables, [only available on request]. Department for Education (Great Britain) (2011) Efficiency and practice review-home-to-school transport. Press Release, Department for Education, London, 12 September (2010c)

Department for Education (DfE) (Great Britain): The School Curriculum. Department for Education, London. http://www.education.gov.uk/schools/teachingandlearning/curriculum (2013a). Accessed 5 Jan 2013

Department for Education (Great Britain): Guidance on home-to-school travel and transport. Department for Education, London (2013)

Department for Transport (Great Britain): Travel to School in GB, Personal Travel Factsheet 2. Department for Transport and Office of National Statistics, Crown Copyright, London (2003)

Department for Transport (Great Britain): National Travel Survey: 2011. Department for Transport, London, 13 December (2012)

Enoch, M.P.: Sustainable Transport, Mobility Management and Travel Plans. Ashgate, Farnham (2012)

Fügenschuh, A.: Solving a school bus scheduling problem with integer programming. Eur. J. Oper. Res. 193(3), 867-884 (2009)

Gao, O.H., Klein, R.A.: Environmental equity in funding decisions of the clean air school bus program: the case of New York State. Transp. Res. D Transp. Environ. 16(1), 10-14 (2011)

Gillard, D.: Education in England: A Brief History. www.educationengland.org.uk/history (2011). Accessed 13 Feb 2014

Goldstein, H.: Multilevel Statistical Models, 3rd edn. Arnold, London (2003)

Headicar, P.: Transport Policy and Planning in Great Britain. Routledge, London (2009)

Hine, J.: The provision of home-to-school transport in Northern Ireland. Res. Transp. Econ. 25(1), 29-38 (2009)

Hochstetler, H.A., Yermakov, M., Reponen, T., Ryan, P.H., Grinshpun, S.A.: Aerosol particles generated by diesel-powered school buses at urban schools as a source of children's exposure. Atmos. Environ. 45(7), 1444-1453 (2011)

Luiselli, J.: Treatment of an autistic child's fear of riding a school bus through exposure and reinforcement. J. Behav. Ther. Exp. Psychiatry 9(2), 169-172 (1978)

Kingham, S., Ussher, S.: Ticket to a sustainable future: an evaluation of the long-term durability of the Walking School Bus programme in Christchurch, New Zealand. Transp. Policy 12(4), 314-323 (2005)

Mackie, P.: Principles of public policy for bus services. In: Grayling, T. (ed.) Any More Fares? Delivering Better Bus Services, pp. 19-39. Institute for Public Policy Research, London (2001)

Marshall, J.D., Wilson, R.D., Meyer, K.L., Rajangam, S.K., McDonald, N.C., Wilson, E.J.: Vehicle emissions during children's school commuting: impacts of education policy. Environ. Sci. Technol. 44(5), 1537-1543 (2010)

Office for National Statistics (ONS) (Great Britain): Regional Trends Statistics 40. Office for National Statistics, London (2006)

de Ortuzar, J.D., Willumsen, L.G.: Modelling Transport, 3rd edn. Wiley, Chichester (2001)

Park, J., Kim, B.I.: The school bus routing problem: a review. Eur. J. Oper. Res. 202(2), 311-319 (2010)

Stiglitz, J.: Freefall: Free Markets and the Sinking of the Global Economy. Penguin, London (2010)

Swartz, M.K., Reilly, E.A.: School bus safety: issues and controversy. J. Pediatr. Health Care 9(3), 145-148 (1995)

Thornthwaite, S.: School journeys, young people's travel, and the role of the bus. In: Grayling, T. (ed.) Any More Fares? Delivering Better Bus Services, pp. 182-193. Institute for Public Policy Research, London (2001)

Thornthwaite, S.: School Transport: Policy and Practice. Landor Publishing, London (2009) 
Transport for London (TfL): Putting the Brakes on the School Run. Press Release, Transport for London, London, 1 October, http://www.tfl.gov.uk/corporate/media/newscentre/archive/9524.aspx (2008). Accessed 10 Jan 2013

UK Parliament: Current School Travel Framework, School Travel-Transport Select Committee, House of Commons. UK Parliament, London, http://www.publications.parliament.uk/pa/cm200809/cmselect/ cmtran/351/35105.htm (2006). Accessed 16 Jan 2013

Van-Ristell, J.A., Enoch, M.P., Quddus, M.A., Wang, C., Hardy, P.: Quantifying the transport-related impacts of school choice policy in the UK. Transportation, 40, 69-90 (2013a)

Van-Ristell, J.A., Enoch, M.P., Quddus, M.A., Hardy, P.: Expert perspectives on the role of the bus in school travel. Munic. Eng. 166(1), 53-58 (2013b)

Whitehurst, C., Miller, E.: Behaviour modification of aggressive behaviour on a nursery school bus: a case study. J. Sch. Psychol. 11(2), 123-128 (1973)

Yang, J.Z., Peek-Asa, C., Cheng, G., Heiden, E., Falb, S., Ramirez, M.: Incidence and characteristics of school bus crashes and injuries. Accid. Anal. Prev. 41(2), 336-341 (2009)

Yellow Bus Commission: Report of the Yellow School Bus Commission. Macmillan House, London (2008)

Zhang, Z., Zhu, Y.: Measurements of ultrafine particles and other vehicular pollutants inside school buses in South Texas. Atmos. Environ. 45(7), 1444-1453 (2010)

Jessica A. Van Ristell graduated with a BSc (Hons) in Air Transport Management from Loughborough University in 2008. She then stayed on at Loughborough to undertake a $\mathrm{PhD}$ on the subject of school travel in England which she completed in 2011, and this was followed by an additional year on the EPSRC and JMP Consultants Ltd-funded project. Dr. Van Ristell has been employed as a Research Analyst in the Operational Analysis Safety Team at NATS (formally known as National Air Traffic Services), specialising in aviation safety since 2012 .

Mohammed A. Quddus is a Professor of Intelligent Transport Systems (ITS) at Loughborough University. His primary research interests include transport systems modelling, sensor fusion using artificial intelligence and analysing large transport datasets. He currently serves as an Associate Editor of Transportation Research Part C and Journal of ITS.

Marcus P. Enoch joined Loughborough University in 2003 and was promoted to be a Senior Lecturer in 2007. He obtained a BEng degree in Civil Engineering (University of Nottingham) in 1993; an MSc degree in Transport Planning and Engineering (University of Leeds) in 1994; and a PhD (Open University) in 1998.

Chao Wang is a Research Statistician at the University of Oxford. He received a BEng degree in Transportation Management (Dalian Maritime University) in 2005; an MSc in Transport (Imperial College London) in 2006; and a PhD (Loughborough University) in 2010. His primary research interests include transport modelling and 'big data'.

Peter Hardy is a Director at JMP Consultants Ltd and has also worked within local government advising and assisting public sector organisations at local, regional and national level. His specialist area is in the field of passenger transport and accessibility matters, and much of his work concerns people, communities and organisations. 